\title{
Proteolytic Analysis of Different Tuna (Thunnus albacares) Viscera for Obtaining Protein Hydrolysates
}

\author{
Jorge Montiel-Montoya ${ }^{1}$ (D), Rafael Salgado-Garciglia ${ }^{2}$ (D) Jesús Antonio Salazar-Magallón ${ }^{2}$ (D), César \\ Reyes Reyes ${ }^{3}$ (D), Jesús Aarón Salazar Leyva ${ }^{4}$, B. Mata-Avila ${ }^{5}$, Adolfo Dagoberto Armenta-Bojórquez ${ }^{1}$, \\ Braulio Edgar Herrera-Cabrera ${ }^{6}$ (D) , Luis Germán López-Valdez ${ }^{7}$ (D), \\ Leticia Mónica Sánchez-Herrera 8 (D), Victor Manuel Ocaño-Higuera 9 (D), \\ Hebert Jair Barrales-Cureño ${ }^{2 *}$ (D)
}

1 Centro Interdisciplinario de Investigación para el Desarrollo Integral Regional, Instituto Politécnico Nacional, Unidad Sinaloa, Boulevard Juan de Dios Bátiz 250, Col. San Joachín, Guasave, Sinaloa, México

2 A Instituto de Investigaciones Químico Biológicas, Universidad Michoacana de San Nicolás de Hidalgo, Edificio B-3, Ciudad Universitaria, Morelia, Michoacán, México

3 Dirección de Investigación. Universidad Intercultural del Estado de Puebla. Calle Principal a Lipuntahuaca S/N, Lipuntahuaca, Huehuetla, Puebla, México

4 Universidad Politécnica de Sinaloa. Carretera Municipal Libre Mazatlán Higueras Km 3, Mazatlán, Sinaloa, México

5 Ingeniería Industrial del Pacífico, S.A. de C.V. (IIPSA). Aguamarina No. 16, Col. Las Delicias

6 Colegio de Postgraduados, Campus Puebla. Boulevard Forjadores No 205 Santiago Momoxpan, Puebla, México

7 Laboratorio de Productos Naturales, Área de Química. AP74 Oficina de correos Chapingo, Universidad Autónoma Chapingo, Km 38.5 Carretera México-Texcoco, Texcoco, Estado de México, México

8 Universidad Autónoma de Nayarit. Ciudad de la Cultura, Amado Nervo, Tepic, Nayarit, México

9 Universidad de Sonora. Blvd. Luis Encinas y Rosales S/N, Col. Centro. Hermosillo, Sonora, México

* Correspondence: hebert.barrales@umich.mx (H.J.B.C.)

Scopus Author ID 57197733909

Received: 4.08.2021; Revised: 30.08.2021; Accepted: 31.08.2021; Published: 4.09.2021

\begin{abstract}
This project aims to obtain and characterize protein hydrolysates from the solid residues (dark muscle) and effluents (cooking water) generated from the processing of yellowfin tuna (Thunnus albacares) and evaluate their potential to be applied as organic fertilizer in farming. From the studied viscera (stomach, pyloric blind, liver, pancreas, and intestine), it was found that the pyloric blind of the tuna digestive system represents an adequate source of alkaline proteases that act on the dark muscle of tuna and cooking water, at $\mathrm{pH}$ optimum of 10.5 and temperature of $50{ }^{\circ} \mathrm{C}$. The results of SDS-PAGE electrophoresis and enzymatic inhibition indicate that the proteolytic activity exhibited by the enzymatic extract of the pyloric blind of tuna is mainly due to serine protease enzymes, especially trypsin type, and it showed a proteolytic activity similar to that of a commercial protease coming from Bacillus sp. It is possible to use these enzymes in processes that require $\mathrm{pH}$ values between 8 and 11 and mild temperatures conditions $\left(30-50^{\circ} \mathrm{C}\right)$. The cooking water showed a low yield and high ash content, which may decrease the protein hydrolysates' nutritional quality and functional properties.
\end{abstract}

Keywords: proteolytic activity; protein hydrolysates; lyophilized protein.

(C) 2021 by the authors. This article is an open-access article distributed under the terms and conditions of the Creative Commons Attribution (CC BY) license (https://creativecommons.org/licenses/by/4.0/).

\section{Introduction}

Fishing production has had an increase in the last decades. Linked to the growth of fish production and the generation of fishery by-products that are traditionally treated like garbage, serious pollution problems have been generated in the fishing ports where the fishing fleets are located. In this respect, it has been established that of the total production of marine organisms, $60 \%$ is handled as waste between viscera, skin, head, and bones [1]. The proper management 
of fishing by-products can lead to the generation of added value for the fishing industry since these are valuable sources of proteins, pigments, vitamins, minerals, and enzymes [2]. One of the main applications of the fishing by-products is obtaining enzymes, being mainly the proteases the most studied group of enzymes and which constitute the largest and most important group in the industry worldwide. One aspect of great relevance is that the proteases obtained from fishing by-products can be used for the enzymatic production of protein hydrolysates, which, having various functional and bioactive properties, can be applied in the agro-food industry [3]. The alkaline proteases of pyloric caeca and intestines are the most important digestive enzymes in fish viscera. The aquatic environment offers an excellent opportunity to provide proteases to the industry since aquatic organisms, compared with terrestrial organisms, possess the same classes of said enzymes but with unique catalytic properties [4]. Recently, greater interest has been generated in the use of fishing by-products as potential sources of protein hydrolysates (HP) and peptides since these molecules exhibit bioactive properties that may be of interest to various areas of industry. HP is defined as a mixture of amino acids from the hydrolysis of proteins, either by chemical means (example: using acid or alkali) or by enzymatic methods, the latter being the most appropriate since enzymatic hydrolysis is a process that does not use toxic chemical compounds and also preserves the nutritional and functional properties of the HP obtained, thus facilitating its application in the pharmaceutical and food industry [5]. Taking into account the above, the objective of this project was to determine the proteolytic activity of different viscera of yellowfin tuna (Thunnus albacares), evaluate the ability to obtain protein hydrolysates from fishery by-products (dark tuna muscle and cooking water). Obtaining the raw tuna extract from the pyloric caecum of the tuna at different enzyme-substrate ratios and hydrolysis temperature in dark muscle and cooking water.

\section{Materials and Methods}

Samples of yellowfin tuna (Thunnus albacares) with an approximate weight of $6.0 \mathrm{~kg}$ were used as raw material, which was provided by the company IIPSA S.A. of C.V. The tuna was stored on ice and transported to the Bioactive Natural Composites Laboratory (LCNB) of the Polytechnic University of Sinaloa. The tuna was left to thaw for 8 hours on the ice, at a temperature of $4 \pm 2{ }^{\circ} \mathrm{C}$. Later the tuna was eviscerated, separating the different parts of the digestive system of the organism. Each of the parts was stored in polyethylene bags sealed at $20{ }^{\circ} \mathrm{C}$ until use. $5.0 \mathrm{~g}$ of each part of the digestive system (stomach, pyloric caeca, liver, pancreas, intestine) were weighed and subsequently homogenized separately with a cold solution of $10 \% \mathrm{NaCl}(\mathrm{w} / \mathrm{v})$ in a 1: 2 ratio. With a food homogenizer (BRAUN) for a space no longer than $2 \mathrm{~min}$. Once the different mixtures were obtained, they were centrifuged (Thermo Scientific) at $7500 \mathrm{rpm}$, for 30 minutes at $4^{\circ} \mathrm{C}$. The supernatants obtained were considered as crude extracts (EC) and stored at $-20^{\circ} \mathrm{C}$ until further analysis.

\subsection{Measurement of protein content.}

The quantification of protein in the $\mathrm{CD}$ was determined using the method established by Bradford (1976) using serum bovine albumin as standard $(0.5 \mathrm{mg} / \mathrm{mL})$ [6]. The blanks were prepared by placing $100 \mu \mathrm{L}$ of distilled water in microtubes and then $1000 \mu \mathrm{L}$ of the Bradford reagent. In the case of EC samples, $100 \mu \mathrm{L}$ of sample and $1000 \mu \mathrm{L}$ of Bradford's reagent were 
added to homogenize the different mixtures in vortexes and then rest the microtubes for 5 minutes at room temperature. Absorbance was recorded at $595 \mathrm{~nm}$.

\subsection{Determination of total proteolytic activity.}

The total proteolytic activity (APT) in the different ECs was determined using $1 \%$ azocasein at alkaline $\mathrm{pH}$ values $(\mathrm{pH}=9$ and 10$)$. The proteolytic activity was determined as established by Sarath et al. (1989) with some modifications. $20 \mu \mathrm{L}$ of the different EC enzymatic extract were mixed with $1000 \mu \mathrm{L}$ of $1 \%$ azocasein $(\mathrm{w} / \mathrm{v})$ dissolved in buffer solution at the different $\mathrm{pH}$ values tested. The reaction mixture was incubated for 30 minutes at room temperature, then stopped the reaction by adding $500 \mu \mathrm{L}$ of trichloroacetic acid (TCA) at $20 \%$ w/v [7]. Once the reaction was stopped, the mixture was refrigerated for 20 minutes and then centrifuged at 14,000 rpm for 30 minutes. Absorbance was recorded at $366 \mathrm{~nm}$. Simultaneously a control was run, in which the reaction was stopped by adding TCA before the substrate. The results of APT were expressed in units of enzymatic activity (U), according to the following equation: $\mathrm{U} / \mathrm{min}=[\mathrm{Abs}$ act - Abs with $] /$ Trx. Where: Abs act absorbance at $366 \mathrm{~nm}$ of the samples, abs with absorbance at $366 \mathrm{~nm}$ from the controls, and Trx reaction time (30 min).

\subsection{Experiments measuring total proteolytic activity with a commercial protease.}

For standardization of the APT determination technique, the determination of enzymatic activity was carried out with a commercial protease (Protease from Bacillus sp., Sigma-Aldrich). A solution was prepared by mixing $0.02 \mathrm{~g}$ of protease with $5 \mathrm{~mL}$ of buffer Tris- $\mathrm{HCl} \mathrm{pH}$ 8. The commercial enzyme sample was diluted $(0.004-4 \mathrm{mg} / \mathrm{mL})$ to determine the APT according to the protocol described above.

\subsection{Obtaining a crude extract of proteases from pyloric blinds of yellowfin tuna.}

$100.0 \mathrm{~g}$ of pyloric caeca from 5 different organisms were weighed and subsequently homogenized separately with a cold solution of $10 \% \mathrm{NaCl}(\mathrm{w} / \mathrm{v})$ in a 1:2 ratio, with a food homogenizer (BRAUN) for a space no larger $2 \mathrm{~min}$. Once the different mixture was obtained, it was centrifuged (Thermo Scientific) at $7500 \mathrm{rpm}$, for 30 minutes at $4^{\circ} \mathrm{C}$. The supernatant obtained was considered the crude extract (EC) and stored at $-20{ }^{\circ} \mathrm{C}$ until further analysis.

\subsection{Determination of total proteolytic activity.}

The total proteolytic activity (APT) of the EC was determined using $1 \%$ azocasein as substrate. The proteolytic activity was determined as established by Sarath et al. (1989) with some modifications. $20 \mu \mathrm{L}$ of the different EC enzymatic extract were mixed with $1000 \mu \mathrm{L}$ of $1 \%$ azocasein $(\mathrm{w} / \mathrm{v})$ dissolved in buffer solution at the different $\mathrm{pH}$ values tested [7]. The reaction mixture was incubated for 30 minutes at room temperature; then, the reaction was stopped by adding $500 \mu \mathrm{L}$ of trichloroacetic acid (TCA) at $20 \% \mathrm{w} / \mathrm{v}$. Once the reaction was stopped, the mixture was refrigerated for 20 minutes and then centrifuged at 14,000 rpm for 30 minutes. Absorbance was recorded at $366 \mathrm{~nm}$. Simultaneously a control was run, in which the reaction was stopped by adding TCA before the substrate. 
2.6. Effect of $\mathrm{pH}$ and temperature on the APT of the EC of pyloric caeca.

The effect of $\mathrm{pH}$ on the APT of the EC was determined using the assay described above. The enzymatic activity was measured in a $\mathrm{pH}$ range of 6 to 13, dissolving the substrate in buffer solution at the corresponding $\mathrm{pH}$. The effect of the temperature on the APT of the enzymatic extract was determined using the $\mathrm{pH}$ where it obtained the highest APT. The temperatures at which the enzymatic activity was measured were the following: 30, 35, 40, 45, 50, 60.70, and $80{ }^{\circ} \mathrm{C}$. To perform this experiment, the substrate used was balanced to the desired temperature, to then run the reaction for 30 minutes at that temperature, allowing maximum variations of \pm $3^{\circ} \mathrm{C}$. For both tests (effect of $\mathrm{pH}$ and temperature), the highest APT value represented $100 \%$ of registered enzymatic activity.

\subsection{Stability of the EC at $\mathrm{pH}$ and at temperature.}

The effect of $\mathrm{pH}$ on the stability of the EC proteases was determined by incubating the enzyme extract at different $\mathrm{pH}$ values (7-12) in a buffer solution at different incubation periods $(10,30,60$, and $90 \mathrm{~min})$ at $25^{\circ} \mathrm{C}$. Temperature stability was evaluated by incubating the EC samples in buffer solution ( $\mathrm{pH} 10.5)$ at different temperatures $\left(30,35,40,45\right.$, and $\left.50{ }^{\circ} \mathrm{C}\right)$ and times $(10,30,60$, and $90 \mathrm{~min})$. At the end of the incubation of the EC under the aforementioned $\mathrm{pH}$ and temperature conditions, the residual APT was determined. $100 \%$ enzymatic activity corresponds to the activity of the EC of proteases without incubation (control).

\subsection{Effect of specific protease inhibitors on the proteolytic activity of EC.}

To elucidate the type of proteolytic activity present in the enzyme extract, it was incubated with different specific protease inhibitors, such as SBTI, PMSF (serine protease inhibitors), EDTA (metalloprotease inhibitor), and $\mathrm{HgCl} 2$ and DTT (inhibitors of cysteine proteases). $10 \mu \mathrm{L}$ of the enzyme extract was mixed with $10 \mu \mathrm{L}$ of the corresponding inhibitor and said mixture was incubated for 60 minutes at $25^{\circ} \mathrm{C}$, to determine the residual enzymatic activity later using $1 \%$ azocasein as substrate. The percentage of inhibition was calculated considering that $100 \%$ of enzymatic activity corresponds to the crude extract incubated in the absence of protease inhibitors $[8,9]$.

\subsection{EC protein composition.}

To determine the molecular weight of the proteins present in the EC, electrophoresis was carried out in $10 \%$ sodium polyacrylamide and dodecyl sulfate (SDS-PAGE) gel under non-reducing conditions.

\subsubsection{Management and preparation of tuna by-products.}

The samples of dark muscle and cooking water were kindly provided by the Industrial Engineering Company of the Pacific (IIPSA), located in Mazatlan, Sinaloa. In the case of the dark muscle of yellowfin tuna, this was collected after the cooking stage and placed in polyethylene bags, to be later transferred to the Bioactive Natural Composites Laboratory (LCNB) of the Polytechnic University of Sinaloa, where they were stored at $-20{ }^{\circ} \mathrm{C}$ until use. In the case of the cooking water, this was collected in polyethylene bottles, placed on ice, and transferred to the LCNB, to be filtered with a blanket of the sky to remove the solids and lipids contained in the sample. The filtrate was stored at $-20{ }^{\circ} \mathrm{C}$ until its later use $[10,11]$. The 
proximal composition (\% proteins, lipids, moisture and ash) of the dark muscle and cooking water was determined using the methods established by the AOAC [12].

\subsubsection{Obtaining protein hydrolysates from dark muscle and cooking water.}

200.0 grams of dark muscle were homogenized with $400 \mathrm{~mL}$ of deionized water, the $\mathrm{pH}$ was adjusted to 8 with $2 \mathrm{M} \mathrm{NaOH}$, and the mixture was pre-incubated for $20 \mathrm{~min}$ at two different temperatures (optimal EC temperature of tuna viscera and alcalase). Before starting the enzymatic hydrolysis. The hydrolysis process was initiated by adding the corresponding enzyme to the homogenate at different enzyme/substrate ratios. The $\mathrm{pH}$ was adjusted with $1 \mathrm{M}$ $\mathrm{NaOH}$ to keep it constant during the hydrolysis process, which was developed for 6 hours. After the corresponding hydrolysis time had elapsed, the reaction mixture was incubated for 20 minutes in a boiling water bath to inactivate the enzymes. Subsequently, the mixture was cooled in ice, the $\mathrm{pH}$ was adjusted to 8 , and the hydrolysates were centrifuged at $10,000 \times \mathrm{g}$ for 10 minutes, at $4{ }^{\circ} \mathrm{C}$. The supernatant obtained was frozen at $-20{ }^{\circ} \mathrm{C}$ to be subsequently lyophilized. In the case of the hydrolysis of the tuna cooking water, $200 \mathrm{~mL}$ of sample was taken, the $\mathrm{pH}$ was adjusted to 8 , and the hydrolysis reaction was carried out following the methodology described above [13].

\subsubsection{Partial chemical characterization of protein hydrolysates.}

The proximal chemical composition (\% proteins, lipids, moisture, and ash) of the protein hydrolysates (HP) obtained after 6 hours of hydrolysis was determined according to the provisions of the AOAC [12].

2.9.4. Nitrogen, phosphorus, potassium, calcium, and magnesium content of protein hydrolysates

The nitrogen determination was made by the Kjeldahl Method. The wet digestion consisted of weighing $0.1 \mathrm{~g}$ of the sample, placing it inside a Kjeldahl flask, adding $1.5 \mathrm{~mL}$ of the sulfuric-salicylic acid mixture. Once the digested solution was obtained, it was transferred quantitatively to the distillation equipment. Subsequently, the titration of each sample was carried out with the solution of $\mathrm{H}_{2} \mathrm{SO}_{4}$ at $0.05 \mathrm{~N}$ until the first turn of color to slightly pink. At the same time, the titration was carried out on a white sample, noting the spent $\mathrm{mL}$ in each sample to perform the corresponding calculations. It was determined by wet digestion $0.5 \mathrm{~g}$ of sample was placed in a $50 \mathrm{~mL}$ Kjeldahl flask. To this was added $10 \mathrm{~mL}$ of concentrated nitric acid $\left(\mathrm{HNO}_{3}\right)$ and allowed to stand for $30 \mathrm{~min}$. Subsequently, $1.5 \mathrm{~mL}$ of perchloric acid $\left(\mathrm{HClO}_{4}\right)$ plus $2.0 \mathrm{~mL}$ of sulfuric acid $\left(\mathrm{H}_{2} \mathrm{SO}_{4}\right)$ (both concentrates) were added. The digested samples were transferred to volumetric flasks of $25 \mathrm{~mL}$, gauged with deionized water, mixed, and filtered with Whatman No. 42 paper. Subsequently, the corresponding dilution was conducted for reading in the UV visible light spectrophotometer at $470 \mathrm{~nm}$. The concentration of phosphorus was determined by a calibration curve in a range of 0 to $25 \mathrm{ppm}$. Potassium $1 \mathrm{~mL}$ of the digestion was transferred to volumetric flasks of $50 \mathrm{~mL}$ and was calibrated with distilled water. From this solution, the samples were read directly in the percentage of transmittance. The Flame-Flamometry emission method was used. Before reading, the Flamometry equipment was adjusted with the calibration curves 5, 15, 20, 25, and $30 \mathrm{ppm}$ with wavelengths of $766.5 \mathrm{~nm}$. For calcium and magnesium, aliquots of $1 \mathrm{~mL}$ of the digestion were placed in 25 $\mathrm{mL}$ volumetric flasks and were calibrated with distilled water. A second dilution was 
performed from this, which consisted of placing $1 \mathrm{~mL}$ aliquots in $10 \mathrm{~mL}$ volumetric flasks, to which $1 \mathrm{~mL}$ of the lanthanum oxide reagent was added and brought to the final volume with distilled water. They were mixed perfectly, and then the corresponding adjustments were made to the Atomic Absorption Spectrophotometer (Spectr AA, 50B, VARIAN), taking into account the absorbance scale.

\section{Results and Discussion}

\subsection{Measurement of protein content.}

To determine the EC protein content of pyloric caeca, a calibration curve was elaborated using bovine serum albumin.

Considering the value of the coefficient of determination obtained (R2), the corresponding curve was used to determine the protein content of the pyloric caecal EC. In carrying out the Bradford method for protein quantification in the pyloric caecal EC, a protein concentration of $4.029 \mathrm{mg} / \mathrm{mL}$ was obtained.

\subsection{Determination of total proteolytic activity.}

The proteolytic activity was determined in a commercial protease solution at different concentrations, using azocasein at $1 \% \mathrm{w} / \mathrm{v}$, dissolved in buffer solution at $\mathrm{pH} 8$. The enzyme concentration increases, the proteolytic activity goes on an increase. In this regard, it can be inferred that by increasing the concentration of commercial protease, the hydrolysis of the substrate is greater, thus causing the release of peptides that are soluble in TCA and were quantified at $366 \mathrm{~nm}$ [7]. Likewise, this behavior is as expected and indicates that the methodology used is reliable to determine total proteolytic activity in enzymatic extracts from the digestive system of tunas. The proteolytic activity in the different ECs was evaluated at $\mathrm{pH}$ values of 9 and 10. In this regard, in Table 1 and Table 2, it can be seen that the highest APT values were obtained in the bowel EC and pyloric caeca.

Table 1. Values of the total proteolytic activity of the different ECs of the digestive system of tuna.

\begin{tabular}{c|c|c|c|c}
\multicolumn{7}{c}{ Total Proteolytic Activity (U) } \\
\hline EC Páncreas & EC Stomach & EC Pyloric blind & EC Liver & EC Intestine \\
\hline $0.00246^{1}$ & $0.00226^{1}$ & $0.0889^{1}$ & $0.0025^{1}$ & $0.025^{1}$ \\
\hline $0.00210^{2}$ & $0.000033^{2}$ & $0.0874^{2}$ & $0.00136^{2}$ & $0.029^{2}$
\end{tabular}

${ }^{1}$ Activity determined at $\mathrm{pH}=9$

${ }^{2}$ Activity determined at $\mathrm{pH}=10$

Table 2. Protein hydrolysis experiments contained in by-products of yellowfin tuna.

\begin{tabular}{|c|c|c|c|c|}
\hline Experiment ${ }^{\text {a }}$ & Used By-product & Type of enzyme & $\begin{array}{c}\text { Ratio enzyme- } \\
\text { substrate }(\% \text { v/v) }\end{array}$ & $\begin{array}{l}\text { Temperature of } \\
\text { hydrolysis }\left({ }^{\circ} \mathrm{C}\right)\end{array}$ \\
\hline 1 & Dark muscle & Alcalase & 1 & 60 \\
\hline 2 & Dark muscle & Alcalase & 1.5 & 60 \\
\hline 3 & Dark muscle & Alcalase & 3 & 60 \\
\hline 4 & Dark muscle & Crude extract tuna proteases & 1 & 40 \\
\hline 5 & Dark muscle & Crude extract tuna proteases & 1.5 & 40 \\
\hline 6 & Dark muscle & Crude extract tuna proteases & 3 & 40 \\
\hline 7 & Cooking water & Alcalasae & 1 & 60 \\
\hline 8 & Cooking water & Alcalase & 1.5 & 60 \\
\hline 9 & Cooking water & Alcalase & 3 & 60 \\
\hline 10 & Cooking water & Crude extract tuna proteases & 1 & 40 \\
\hline 11 & Cooking water & Crude extract tuna proteases & 1.5 & 40 \\
\hline 12 & Cooking water & Crude extract tuna proteases & 3 & 40 \\
\hline
\end{tabular}

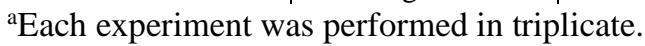


This behavior is consistent with what has been observed for several tuna species, where enzymatic activities elevated to alkaline $\mathrm{pH}$ are reported in proteases extracted from the intestine and pyloric caeca. This behavior is because there is a high concentration of alkaline proteases in these areas of the digestive system. The low activity detected in the EC from the tuna stomach is attributed to the fact that in this part of the viscera are concentrated aspartic proteases, which have optimum $\mathrm{pH}$ of catalysis in a $\mathrm{pH}$ range of 1.5 to 3 . As regards the low proteolytic activity detected in the pancreas and liver, it can be related to the fact that these organs have lipase enzymes in a higher concentration. Due to the high values of total proteolytic activity detected in the pyloric caecal EC, it is planned to use this part of the visceral package of yellowfin tuna ( $T$ albacares) to obtain protein hydrolysates in subsequent stages of the present project.

\subsection{Effect of $\mathrm{pH}$ and temperature.}

Figure 1 shows the effect of $\mathrm{pH}$ on the proteolytic activity of the EC. It is possible to observe that the optimum $\mathrm{pH}$ of EC catalysis was obtained at $\mathrm{pH} 10.5$. In addition, it can be seen that the EC maintained its proteolytic activity above $60 \%$ in a wide range of $\mathrm{pH}$ (7-13), a characteristic that allows us to infer that the proteases contained in the EC could be used in biotechnological processes where $\mathrm{pH}$ is needed neutral-alkaline. The enzymatic activity suffered a considerable decrease at $\mathrm{pH}$ values of 6 and 13, coincides with that reported by other studies where alkaline proteases of various tuna species have been studied. The effect of temperature on the proteolytic activity of the EC was determined, observing that the optimum catalysis temperature was at $50{ }^{\circ} \mathrm{C}$ (Figure 1).
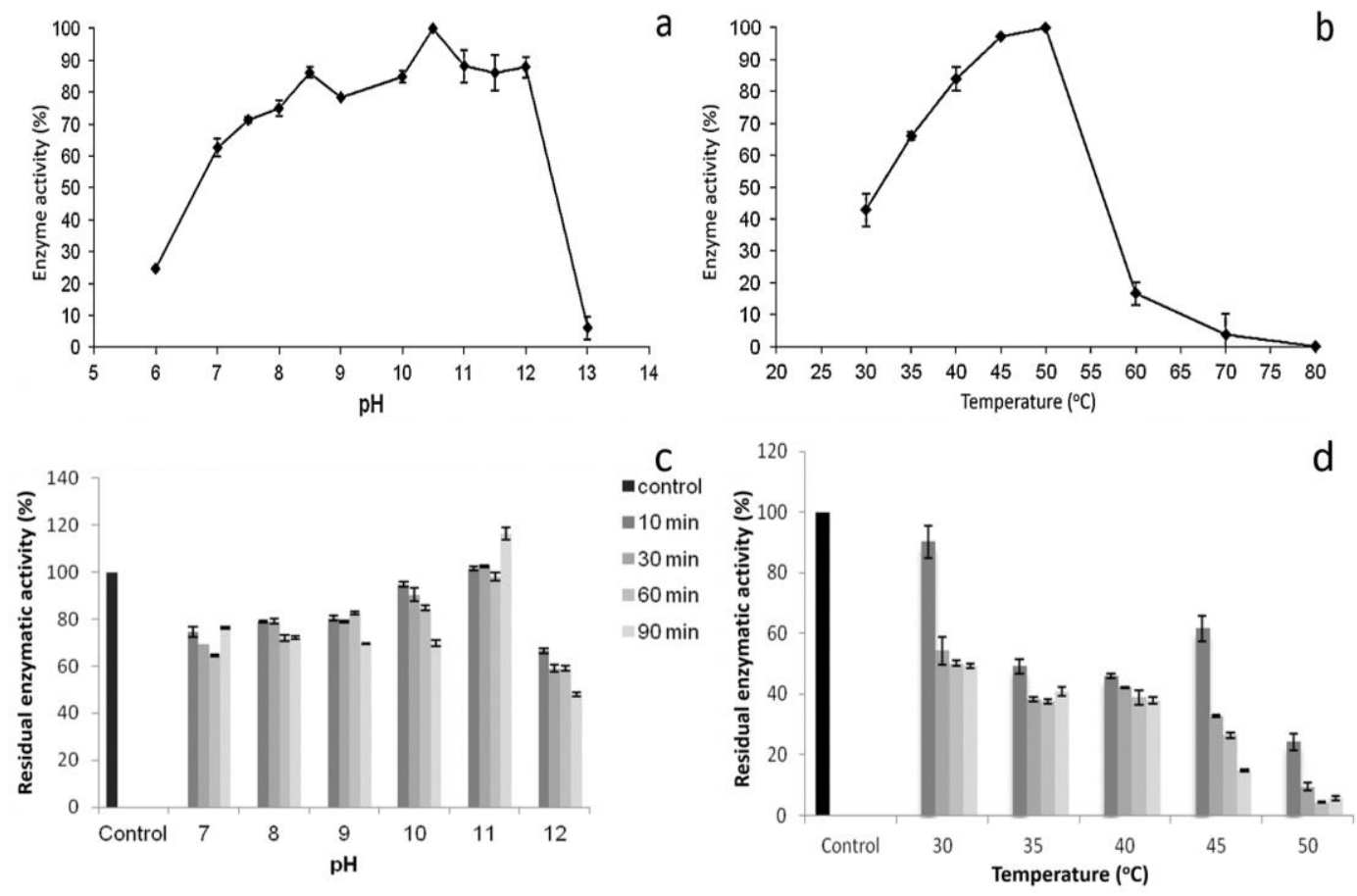

Figure 1. (a) Effect of $\mathrm{pH}$ on the enzymatic activity of the crude extract of pyloric caeca of yellowfin tuna ( $T$. albacares); (b) Effect of temperature on the enzymatic activity of the crude extract of pyloric caeca of yellowfin tuna (T. albacares); (c) Stability at the $\mathrm{pH}$ of proteases contained in the crude extract of pyloric caeca of yellowfin tuna (T. albacares); (d) Temperature stability of proteases contained in the crude extract of pyloric caeca of yellowfin tuna (T. albacares). Each value represents the average of three repetitions \pm D.E. (Standard deviation).

This result is similar to that reported by Byun et al. (2002), who observed that the optimal temperature of a serine protease purified from pyloric tuna caeca (T. thynnus) exhibited 
its maximum catalytic activity at $55^{\circ} \mathrm{C}$ [14]. It is also possible to observe that the enzymatic activity of the EC remained above $60 \%$ in the temperature range between $35-50{ }^{\circ} \mathrm{C}$, which is relevant since, in this temperature range, various biotechnological processes can be catalyzed, such as obtaining protein hydrolysates. The enzymatic activity drastically decreased at temperatures above $50{ }^{\circ} \mathrm{C}$, which may be related to the denaturation of the proteins that make up the $\mathrm{EC}$ of pyloric caeca.

In figure $1 \mathrm{a}$, it is observed that the proteases of the $\mathrm{EC}$ maintained a greater proteolytic activity in the $\mathrm{pH}$ range of 10 to 12, inclusive even after 90 minutes of incubation in the $\mathrm{pH}$ range of 7 to 11, the extract exhibited by up to $60 \%$ enzymatic activity, which indicates high stability of the enzymes present in the EC at alkaline $\mathrm{pH}$. Also, the enzymatic activity decreased to a greater extent when the $\mathrm{EC}$ was incubated at $\mathrm{pH} 12$. The stability at a specific $\mathrm{pH}$ value of the alkaline proteases (for example, trypsin) can be related to the enzymes' net charge at that specific $\mathrm{pH}$ value. In this regard, the decrease in the proteolytic activity of tuna EC at $\mathrm{pH} 12$ may be related to conformational changes of the extract enzymes, causing them not to bind adequately with the substrate. Likewise, Other authors observed that three isoforms of trypsin from "bonito" tuna (Katsuwonus pelamis) presented great stability at pH values between 6 and 11. In Figure $1 b$, the thermal stability of the proteases in the enzymatic extract of pyloric tuna caeca. The extract's proteases present their greater stability in the temperature range of 30 to $40{ }^{\circ} \mathrm{C}$, maintaining up to $40 \%$ of enzymatic activity even at incubation times of $90 \mathrm{~min}$. At higher temperatures $\left(45\right.$ and $50{ }^{\circ} \mathrm{C}$ ), the proteolytic activity of the extract decreased considerably, which can be related to the thermal denaturation of the proteases. The alkaline proteolytic activity of bluefin tuna enzymatic extracts was very sensitive to incubation at high temperatures $\left(40,50\right.$, and $\left.60^{\circ} \mathrm{C}\right)$.

\section{composition.}

3.4. Effect of specific inhibitors of proteases on the enzymatic activity of the EC and EC protein

The type of predominant proteolytic activity in the crude extract was elucidated through the use of specific protease inhibitors. In Figure 2a, it can be seen that the soybean trypsin inhibitor (SBTI) was the one that caused the greatest decrease in the enzymatic activity of the extract ( $80 \%$ ), followed by the PMSF inhibitor, which inhibited about $88 \%$ of the enzymatic activity. These results confirm the presence of trypsin-like alkaline proteases and chymotrypsin in the crude tuna extract and agree with that found in other studies carried out with enzymatic extracts obtained from the intestine and pyloric caeca from various species of tropical fish [14]. Additionally, the lower percentages of inhibition observed with the inhibitors of cysteine proteases (DTT and $\mathrm{HgCl}_{2}$ ) and metalloproteases (EDTA) indicate that this type of proteolytic enzyme does not represent the predominant enzymatic activity in the enzymatic tuna extract (Figure 2).

The protein composition of the enzymatic tuna extract was determined by SDS-PAGE electrophoresis (Figure 2). Different bands of different molecular weights were observed, finding a greater presence of proteins between 66.2 and $21.5 \mathrm{kDa}$. In Figure $2 \mathrm{~b}$, some bands distributed in the molecular weight range between 23 and $31 \mathrm{kDa}$ can be observed, which could be related to the presence of enzymes of the trypsin type, since these alkaline proteases are very abundant in the intestinal tract. the great majority of marine fish. Other authors reported that the molecular weight of three isoforms of purified trypsin from the digestive system of "bonito" tunas (Katsuwonus pelamis) showed a molecular weight of around $24 \mathrm{kDa}$. On the other hand, 
the activity of alkaline proteases obtained from the intestine of bluefin tuna (T. thynnus) may be related to intestinal enzymes with molecular weights between 16.8 and $26.8 \mathrm{kDa}$.

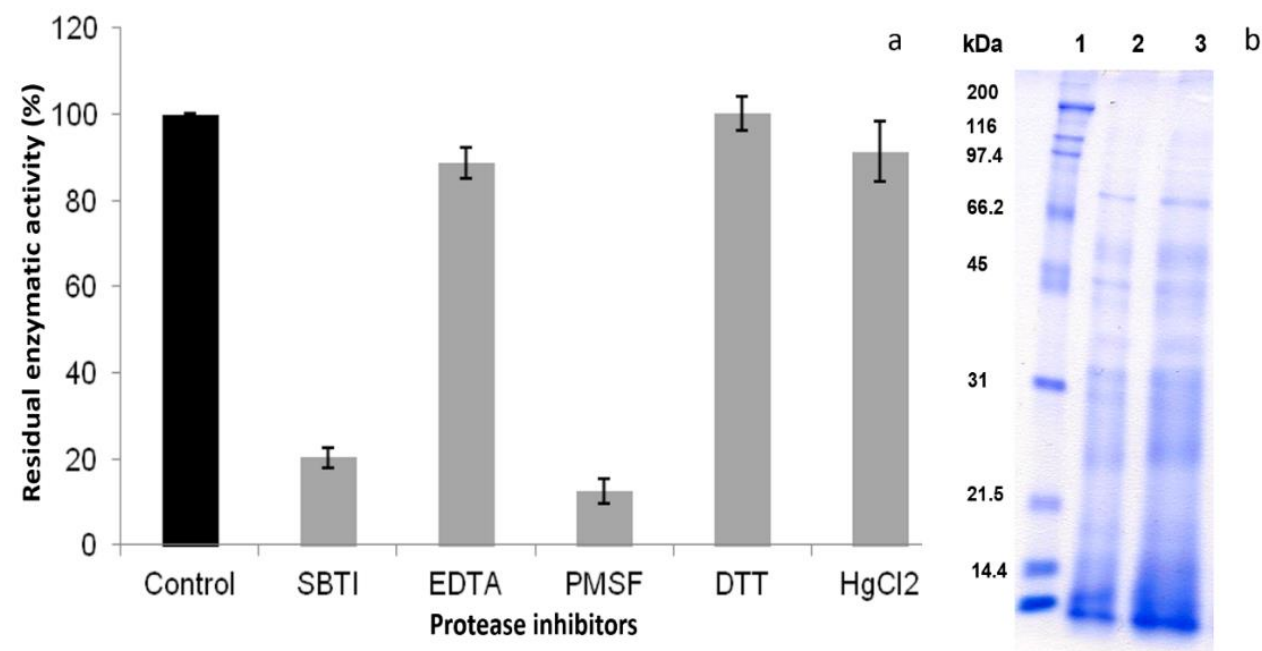

Figure 2. (a) Effect of inhibitors on the residual enzymatic of the crude extract of tuna proteases. Each value represents the average of three repetitions \pm D.E. (Standard deviation); (b) Polyacrylamide gel and sodium dodecyl sulfate. Lane 1: Molecular weight marker (MPM). Lane 2 and 3: crude extract of proteases from pyloric tuna caeca (15 and $20 \mu \mathrm{L}$ of injection volume, respectively).

3.5. Estimated yields of obtaining protein hydrolysates of tuna subproducts at the laboratory level.

A relevant aspect to consider when establishing new biotechnological processes is the yield of obtaining the final product. In this respect, it was found that from $100 \mathrm{~mL}$ of cooking water protein hydrolyzate (after $6 \mathrm{~h}$ of hydrolysis), $4.16 \mathrm{~g}$ of lyophilized hydrolyzate were obtained. In the case of dark meat, from $100 \mathrm{~mL}$ of protein hydrolyzate, $13.3 \mathrm{~g}$ of lyophilized hydrolyzate were obtained. Proximal composition of raw material used to obtain protein hydrolysates. In this study, the dark muscle of yellowfin tuna was used as a protein source to obtain protein hydrolysates. In this context, it is known that the dark muscle of various fish species has limited uses because it is a material that oxidizes easily and does not have a pleasant taste for the consumer. Generally, this type of muscle is converted into low commercial value products, so the conversion of this muscle into protein hydrolysates could lead to the generation of value-added products [16]. In Table 3, the proximal composition of the tuna by-products used in this study can be appreciated.

Table 3. Proximal composition of yellowfin tuna (Thunnus albacares) by-products.

\begin{tabular}{|c|c|c|c|c|}
\hline \multirow[t]{2}{*}{ Sample } & \multicolumn{4}{|c|}{ Composition $(\%)^{\mathrm{a}}$} \\
\hline & Humidity & Protein & Lipids & Ashes \\
\hline Dark muscle & $66.8 \pm \quad 0.11$ & N.D. & $5.9 \pm 0.02$ & $8.1 \pm 0.02$ \\
\hline Dark muscle macerate & $86.9 \pm 0.5$ & N.D. & $6.1 \pm 0.22$ & $7.5 \pm 0.31$ \\
\hline Filtered cooking water & $93.7 \pm 0.05$ & N.D. & $1.2 \pm 0.10$ & $46.5 \pm 0.28$ \\
\hline
\end{tabular}

${ }^{a}$ All values are expressed on a wet basis and represent the mean of three determinations \pm S.D. (Standard deviation).

N.D. $=$ Not determined

In the case of the dark muscle of yellowfin tuna (T. albacares), it was observed that its moisture content is similar to that reported by Hsu (2010), who worked with the tuna T. tonggol, whose muscle has a moisture percentage value of $71.3 \%$, while the lipid and ash content of the yellowfin tuna used in this study was higher than that reported for the T. tonggol tuna $(2.3 \%$ 
and $1.29 \%$ lipid and ash content, respectively) [16]. In addition to the above, it is known that the chemical composition of the fish muscle depends on factors such as species, size, maturity, sex, and activity of the specimen. On many occasions, great differences can be found in the proximal composition, even between organisms of the same species. These differences are usually attributed to the state of sexual development of the organism, as well as to its feeding conditions [17]. For the case of the macerated dark muscle (dark muscle + water, ratio 1:2) used in this study as a raw material to obtain protein hydrolysates, it was observed that, as expected, its moisture content increased concerning the dark muscle without macerating, whereas its content of lipids and ashes was very similar to the unmacerated muscle.

Besides the generation of solid fishing by-products, the liquids are also the most relevant effluents generated during operations such as the washing, thawing, and cooking of marine organisms [18]. The most common management of these by-products consists in their use for the manufacture of animal feed (mainly in the form of flour); however, a large proportion of these by-products are inadequately disposed towards the environment either by throwing them directly into the sea or in the coasts, wharves and jetties causing ecological problems [19, 20]. Therefore, this study decided to explore the obtaining of protein hydrolysates from the cooking water resulting from the processing of yellowfin tuna. The proximal composition of the filtered cooking water can be seen in Table 3. Being affluent, the moisture content of the cooking water was very high $(93.7 \%)$, while its lipid content was similar to that reported by Garcia-Sifuentes et al. (2009) [21] for tailwater from the sardine industry, which presented $1.8 \%$ lipids. Similar results were observed by Bechtel (2005) [22], who found that the lipid content of tailwater generated from cod and salmon by-product processing was 2.59 and $1.80 \%$, respectively. Regarding the ash content, the filtered cooking water presented a high amount of ash (46.5\%) compared to that reported by other authors. For example, the tailwater of the sardine industry contains about $1.7 \%$ ash [21], while the tailwater of cod and salmon by-products presented 13.9 and $10.6 \%$ ash [22].

3.6. Proximal composition of protein hydrolysates obtained from by-products of yellowfin tuna (Thunnus albacares).

The chemical composition of food products plays a very important role in consumer health. In relation to this, the chemical composition of protein hydrolysates is a very important feature. Depending on their nutritional quality, these hydrolysates can positively affect human and animal health [23]. The moisture content of the samples of protein hydrolysates obtained from the dark muscle of yellowfin tuna was in the range of 0.1 to $6.5 \%$ (Table 4 and Table 5).

Table 4. Proximate composition of lyophilized protein hydrolysates obtained from by-products of yellowfin tuna (Thunnus albacares).

\begin{tabular}{l|c|c|c}
\multirow{2}{*}{ Sample } & \multicolumn{3}{|c}{ Composition $(\%)^{\mathbf{a}}$} \\
\cline { 2 - 4 } HMOALC-1 & Humidity & Lípids & Ashes \\
\hline HMOALC-1.5 & $6.5 \pm 0.2$ & $3.9 \pm 0.03$ & $14.4 \pm 0.1$ \\
\hline HMOALC-3 & $0.1 \pm 0.006$ & $3.3 \pm 0.05$ & $13.8 \pm 0.1$ \\
\hline HMOEC-1 & $1.5 \pm 0.08$ & $2.1 \pm 0.08$ & $14.7 \pm 0.2$ \\
\hline HMOEC-1.5 & $1.5 \pm 0.04$ & $4.2 \pm 0.04$ & $13.5 \pm 0.01$ \\
\hline HMOEC-3 & $2.1 \pm 0.07$ & $4.1 \pm 0.04$ & $13.9 \pm 0.03$ \\
\hline HACALC-1 & N.D. & $3.6 \pm 0.03$ & $16.6 \pm 0.1$ \\
\hline HACALC-1.5 & N.D. & $0.6 \pm 0.007$ & $54.6 \pm 0.07$ \\
\hline HACALC-3 & N.D. & $0.09 \pm 0.01$ & $53.8 \pm 0.2$ \\
\hline HACEC-1 & N.D. & $0.2 \pm 0.01$ & $51.6 \pm 0.3$ \\
\hline HACEC-1.5 & N.D. & $0.6 \pm 0.001$ & $51.5 \pm 0.5$ \\
\hline HACEC-3 & N.D. & $0.9 \pm 0.03$ & $50.7 \pm 0.1$ \\
\hline
\end{tabular}


${ }^{a}$ All values are expressed on a dry basis and represent the mean of three determinations \pm S.D. (standard deviation). HMOALC-1= Dark muscle hydrolyzate with $1 \%$ v/v alcalase enzyme.

HMOALC-1.5 = Dark muscle hydrolyzate with alcalase enzyme at $1.5 \% \mathrm{v} / \mathrm{v}$.

HMOALC-3 = Dark muscle hydrolyzate with alcalase enzyme at $3 \% \mathrm{v} / \mathrm{v}$.

HMOEC-1 = Dark muscle hydrolyzate with crude tuna protease extract at $1 \% \mathrm{v} / \mathrm{v}$.

HMOEC-1.5= Dark muscle hydrolyzate with crude tuna protease extract at $1.5 \% \mathrm{v} / \mathrm{v}$.

HMOEC-3 = Dark muscle hydrolyzate with crude tuna protease extract $3 \% \mathrm{v} / \mathrm{v}$.

HACALC-1 = Cooking water hydrolyzate with $1 \% \mathrm{v} / \mathrm{v}$ alcalase enzyme.

HACALC-1.5 = Hydrolyzed cooking water with alcalase enzyme at $1.5 \% \mathrm{v} / \mathrm{v}$.

HACALC-3= Cooking water hydrolyzate with $3 \%$ v/v alcalase enzyme.

HACEC-1 = Hydrolyzed cooking water with crude extract of tuna proteases at $1 \% \mathrm{v} / \mathrm{v}$.

HACEC-1.5= Cooking water hydrolysate with crude extract of tuna proteases at $1.5 \% \mathrm{v} / \mathrm{v}$.

HACEC-3= Hydrolyzed cooking water with crude extract of tuna proteases $3 \% \mathrm{v} / \mathrm{v}$.

Table 5. Comparison of $\mathrm{N}, \mathrm{P}, \mathrm{K}, \mathrm{Ca}$, and $\mathrm{Mg}$ concentration in different hydrolysates.

\begin{tabular}{l|c|c|c|c|c|c} 
& HCO 1\% & HCO & HCO & HCO ECP & HCO & $\begin{array}{c}\text { Hydrolyzed dark meat blind } \\
\text { extract blind 3 \% }\end{array}$ \\
\hline Analysis 1: N \% & 9.1 & 9.4 & 8.5 & 8.0 & 8.8 & 9.0 \\
\hline Analysis 2: P \% & 1.11 & 1.18 & 1.14 & 1.19 & 1.18 & 1.18 \\
\hline Analysis 3: K \% & 0.67 & 0.82 & 0.72 & 0.67 & 0.80 & 0.80 \\
\hline Analysis 4:Ca \% & 0.78 & 0.69 & 0.80 & 0.67 & 0.85 & 0.89 \\
\hline Analysis 5: $\mathrm{Mg} \%$ & 0.26 & 0.24 & 0.25 & 0.20 & 0.24 & 0.29
\end{tabular}

HCO $1 \%=$ Hydrolyzed of dark flesh $1 \%$

HCO EPC $1 \%=$ Hydrolyzed of dark fesh extractum and pyloric blind $1 \%$

HCO $1.5 \%=$ Hydrolysed dark meat $1.5 \%$

HCO ECP $1.5 \%=$ Hydrolysed dark meat extract pyloric blind 1.5\%.HCO 3\% = Hydrolyzed dark meat $3 \%$.

The protein hydrolyzate of by-products of tilapia (Oreochromis niloticus) dried by spray had $6.48 \%$ humidity. Similar results were obtained by Nilsang et al. (2005) [24, 25], who obtained protein hydrolysates of tuna by-products with a $7.25 \%$ humidity. The low moisture content of the hydrolysates can be related to the type of sample used to obtain them, as well as to the drying operations to which they are subjected [26]. In relation to the lipid content of the protein hydrolysates, it is observed that the hydrolysates from dark muscle presented a higher percentage of lipids than those obtained from cooking water. This behavior could be related to the differences in the lipid content of the raw materials used to obtain the hydrolysates; For example, the dark muscle of tuna has a higher lipid content than that of boiling water. According to the specialized literature, most studies indicate that the lipid content of fish protein hydrolysates is less than 5\%. This data agrees with the results of this study since the hydrolysate with the highest lipid content presented $4.2 \%$ of this component. As an example, Pacheco-Aguilar et al. (2008) reported that lyophilized hydrolyzed hake muscle (Merluccius productus) presented $0.3 \%$ of lipids. The low lipid content of the tuna by-product hydrolysates may be related to the fact that many of the lipid components were removed together with the non-soluble protein fraction during the centrifugation process of the hydrolysates (Chalamaiah et al., 2012). The number of ashes of the protein hydrolysates, I oscillate between $13.5 \%$ and $54.6 \%$, being very noticeable that the hydrolysates obtained from cooking water had a higher ash content than the dark muscle hydrolysates. This behavior is related to the fact that, as previously discussed, the cooking water used in this investigation has a very high ash content compared to samples of dark tuna muscle. It has been reported that, in general, the ash content in fish protein hydrolysates can range between $0.45 \%$ and $27 \%$ of its total composition. For example, Nilsang et al. (2005) obtained protein hydrolysates from fish soluble from the cooking of tuna by-products and reported that the hydrolysate contained $26 \%$ ash. It has been mentioned that the high ash content of some fish protein hydrolysates can be caused by the 
addition of acid or base used to adjust the $\mathrm{pH}$ of the reaction medium [27]. The dark yellowfin tuna muscle is outlined as a suitable by-product to obtain protein hydrolysates because a higher yield is obtained in hydrolysis and its ash and lipid content are within limits established for fish protein hydrolysates. Protein hydrolysates from tuna fish are attractive as biofertilizers because they have a high nitrogen concentration ( 8 to $9.4 \%$ ); higher than traditional organic fertilizers.

\section{Conclusions}

Proteases obtained from fish by-products can be used for the enzymatic production of protein hydrolysates, which possess diverse functional and bioactive properties and can be applied in agriculture. From the results obtained in this stage, it is concluded that the pyloric blinds of the tuna digestive system represent an adequate source of alkaline proteases. The crude pyloric caecum extract showed a proteolytic activity similar to that of a commercial protease from Bacillus sp., Which demonstrates the potential for using the crude extract of alkaline proteases of pyloric caecates to obtain protein hydrolysates. The results of SDS-PAGE electrophoresis and enzymatic inhibition indicate that the proteolytic activity exhibited by the enzymatic extract of tuna pyloric caecae is mainly due to serine protease enzymes, especially of the trypsin type. The temperature stability of the extract proteases suggests that they can be used to hydrolyze protein at mild temperature conditions $\left(30-40^{\circ} \mathrm{C}\right)$. Also, the marked stability to the alkaline $\mathrm{pH}$ of the extract allows visualizing that it is possible to use these enzymes in processes assisted by enzymes where $\mathrm{pH}$ values between 8 and 11 are required. It was possible to obtain protein hydrolysates from fishery by-products such as dark muscle of yellowfin tuna and cooking water. The low yield of obtaining lyophilized protein hydrolyzate from cooking water may indicate that this fishing effluent may represent a problem in terms of its handling for obtaining hydrolysates at the pilot or industrial plant level. Likewise, the high ash content of the cooking water may represent a decrease in the nutritional quality and functional properties of the obtained protein hydrolysates. Conversely, the dark muscle of yellowfin tuna is outlined as a suitable by-product to obtain protein hydrolysates; this is because, from this raw material, a higher hydrolyzate production yield is obtained, in addition to its content of ashes and lipids are within limits established for fish protein hydrolysates. Protein hydrolysates are attractive to use as biofertilizers because they have a higher nitrogen concentration than traditional organic fertilizers.

\section{Funding}

This research received no external funding.

\section{Acknowledgments}

We thank the Consejo Nacional de Ciencia y Tecnología (CONACYT) for the postdoctoral fellowship grant for the realization of this project.

\section{Conflicts of Interest}

The authors declare no conflict of interest. 


\section{References}

1. Sampantamit, T.; Ho, L.; Van Echelpoel, W.; Lachat, C.; Goethals, P. Links and Trade-offs between fisheries and environmental protection in relation to the sustainable development goals in Thailand. Water 2020, 12, 399, https://doi.org/10.3390/w12020399.

2. Caruso, G.; Floris, R.; Serangeli, C.; Di Paola, L. Fishery wastes as a yet undiscovered treasure from the sea: biomolecules sources, extraction methods and valorization. Mar. Drugs 2020, 18, https://doi.org/10.3390/md18120622.

3. Lukin, A. Application and comparison of proteolytic enzyme preparations in technology of protein hydrolyzates. J Food Sci Technol 2020, 40, 287-292, https://doi.org/10.1590/fst.09319.

4. Osuna-Ruiz, I.; Espinoza-Marroquin, M.F.; Salazar-Leyva, J.A.; Peña E.; Álvarez-González, C.A.; BañuelosVargas, I.; Martínez-Montaño, E. Biochemical characterization of a semi-purified aspartic protease from sea catfish Bagre panamensis with milk-clotting activity. Food Sci Biotechnol 2019, 28, 1785-1793, https://doi.org/10.1007/s10068-019-00614-8.

5. Navarro-Peraza, R.E.; Osuna-Ruiz, I.; Lugo-Sánchez, M.E.; Pacheco-Aguilar, R.; Ramírez-Suárez, J.C.; Burgos-Hernández, A.; Martínez-Montaño, E.; Salazar-Leyva, J.A. Structural and biological properties of protein hydrolysates from seafood by-products: a review focused on fishery effluents. J Food Sci Technol 2020, 40, 1-5, https://doi.org/10.1590/fst.24719.

6. Bradford, M.M. A rapid and sensitive method for the quantitation of microgram quantities of protein utilizing the principle of protein-dye binding. Anal Biochem 1976, 72, 248-254, https://doi.org/10.1016/00032697(76)90527-3.

7. Sarath, G.; de La Motie, R.; Wagner, F. Protease assay methods. In Proteolytic Enzymes: A Practical Approach. Beynon, R.; Bond, J. editors. 1989; pp. 25-56.

8. Castillo-Yánez, F.J.; Pacheco-Aguilar, R.; García-Carreño, F.L.; de los Ángeles Navarrete-Del, M. Isolation and characterization of trypsin from pyloric caeca of Monterey sardine Sardinops sagax caerulea. Comp Biochem Physiol 2005, 140, 91-98, https://doi.org/10.1016/j.cbpc.2004.09.031.

9. Garcia-Carreño, F.L.; Haard, N.F. Characterization of proteinase classes in langostilla (Pleuroncodes planipes) and crayfish (Pacifastacus astacus) extracts. J Food Biochem 1993, 17, 97-113

10. Hsu, K.C.; Li-Chan, E.C.Y.; Jao, C.L. Antiproliferative activity of peptides prepared from enzymatic hydrolysates of tuna dark muscle on human breast cancer cell line MCF-7. Food Chem 2011, 126, 617-622, https://doi.org/10.1016/j.foodchem.2010.11.066.

11. Hung, C.C.; Yang, Y.H.; Kuo, P.F.; Hsu, K.C. Protein hydrolysates from tuna cooking juice inhibit cell growth and induce apoptosis of human breast cancer cell line MCF-7. J. Funct Foods 2014, 11, 563-570, https://doi.org/10.1016/j.jff.2014.08.015.

12. William, H. Official methods of analysis of AOAC international. USA. AOAC International Suite 2000, 500, 481.

13. 13 Pacheco-Aguilar, R.; Mazorra-Manzano, M.A.; Ramírez-Suárez, J.C. Functional properties of fish protein hydrolysates from Pacific whiting (Merluccius productus) muscle produced by a commercial protease. Food Chem 2008, 109, 782-789, https://doi.org/10.1016/j.foodchem.2008.01.047.

14. Byun, H.G.; Park, P.J.; Sung, N.I.; Kim, S.K. Purification and characterisation of a serine proteinase from the tuna pyloric caeca. Food Biochem. 2007, 26, 479-494, https://doi.org/10.1111/j.1745-4514.2002.tb00768.x.

15. de la Parra, A.M.; Rosas, A.; Lazo, J.P.; Viana, M.T. Partial characterization of the digestive enzymes of Pacific bluefin tuna Thunnus orientalis under culture conditions. Fish Physiology and Biochemistry 2007, 33, 223-231, https://doi.org/10.1007/s10695-007-9134-9.

16. Hsu, K.C. Purification of antioxidative peptides prepared from enzymatic hydrolysates of tuna dark muscle by-product. Food Chem 2010, 122, 42-48, https://doi.org/10.1016/j.foodchem.2010.02.013.

17. Dunajski, E. Texture of fish muscle. J Texture Stud 1980, 10, 301-318, https://doi.org/10.1111/J.17454603.1980.TB00862.X.

18. Ferraro, V.; Carvalho A.P.; Piccirillo, C.; Santos, M.M.; Castro, P.M.; Pintado, M.E. Extraction of high added value biological compounds from sardine, sardine-type fish and mackerel canning residues-A review. Mater Sci Eng C 2013, 33, 3111-3120, https://doi.org/10.1016/j.msec.2013.04.003.

19. Roslan, J.; Yunos, K.F.M.; Abdullah, N.; Kamal, S.M.M. Characterization of fish protein hydrolysate from tilapia (Oreochromis niloticus) by-product. Agric Agric Sci Procedia 2014, 2, 312-319, https://doi.org/10.1016/j.aaspro.2014.11.044.

20. Arvanitoyannis, I.S.; Kassaveti, A. Fish industry waste: treatments, environmental, current and potential uses. Int J. Food Sci Technol 2008, 43, 726-745, https://doi.org/10.1111/j.1365-2621.2006.01513.x.

21. Garcia-Sifuentes, C.; Pacheco-Aguilar, R.; Lugo-Sanchez, M.; Garcia-Sanchez, G.; Ramirez-Suarez, J.; Garcia-Carreno, F. Properties of recovered solids from stick-water treated by centrifugation and $\mathrm{pH}$ shift. Food Chem 2009, 114, 197-203, https://doi.org/10.1016/j.foodchem.2008.09.064.

22. Bechtel, P.J. Properties of stickwater from fish processing by-products. J Aquat Food Prod Technol 2005 , 14, 25-38, https://doi.org/10.1300/J030v14n02_03. 
23. Karami, Z.; Akbari-Adergani, B. Bioactive food derived peptides: a review on correlation between structure of bioactive peptides and their functional properties. J Food Sci Technol 2019, 56, 535-547, https://doi.org/10.1007/s13197-018-3549-4.

24. Chalamaiah, M.; Hemalatha, R.; Jyothirmayi, T. Fish protein hydrolysates: Proximate composition, amino acid composition, antioxidant activities and applications: A review. Food Chem 2012, 135, 3020-3038, https://doi.org/10.1016/j.foodchem.2012.06.100.

25. Nilsang, S.; Lertsiri, S.; Suphantharika, M.; Assavanig, A. Optimization of enzymatic hydrolysis of fish soluble concentrate by commercial proteases. J Food Eng 2005, 70, 571-578, https://doi.org/10.1016/j.jfoodeng.2004.10.011.

26. Oyinloye, T.M.; Yoon, W.B. Effect of Freeze-Drying on Quality and Grinding Process of Food Produce: A Review. Process 2020, 8, https://doi.org/10.3390/pr8030354.

27. Choi, Y.J.; Hur, S.; Choi, B.D.; Konno, K.; Park, J.W. Enzymatic hydrolysis of recovered protein from frozen small croaker and functional properties of its hydrolysates. J Food Sci 2009, 74, 17-24, https://doi.org/10.1111/j.1750-3841.2008.00988.x. 